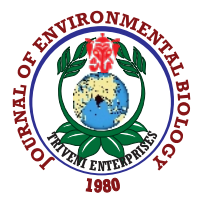

\title{
Ecological impacts of a city forest and level of public awareness for recreational use of Nigde Atatürk city forest
}

\author{
F.C. Karafaki ${ }^{1 *}$ and Ç. Çetin ${ }^{2}$ \\ ${ }^{1}$ Program of Tourism and Hotel Management Program Introduction, Ankara University, Ankara, 06730, Turkey \\ ${ }^{2}$ Department of Interior Architecture and Environmental Design, Yasar University, Izmir, 35100, Turkey \\ *Corresponding Author Email : filizcetinkaya@gmail.com
}

Paper received: 13.04 .2019

Revised received: 30.09 .2019

Accepted: 16.12 .2019

\section{Abstract}

Aim: To explain the impacts of city forests on urban ecology and reveal the level of public awareness of Nigde Ataturk City Forest among the residents of Nigde.

Methodology: Extensive field observations were performed in addition to literature review. A semiquestionnaire study was conducted by using random sampling method in order to measure the level of public awareness.

Results: The city forests play a crucial role in enhancing the urban environmental quality and have numerous ecological benefits for the city. It was found that the participants had insufficient awareness about the benefits of Nigde Atatürk City Forest as regards the ecology and social life of the city.

Interpretation: Urban forests add many economic, ecological, aesthetic and social values to the cities. Urban users should be informed about the benefits and use of urban forest.

Key Words: City Forest, Ecology, Nigde Ataturk City Forest, Recreation

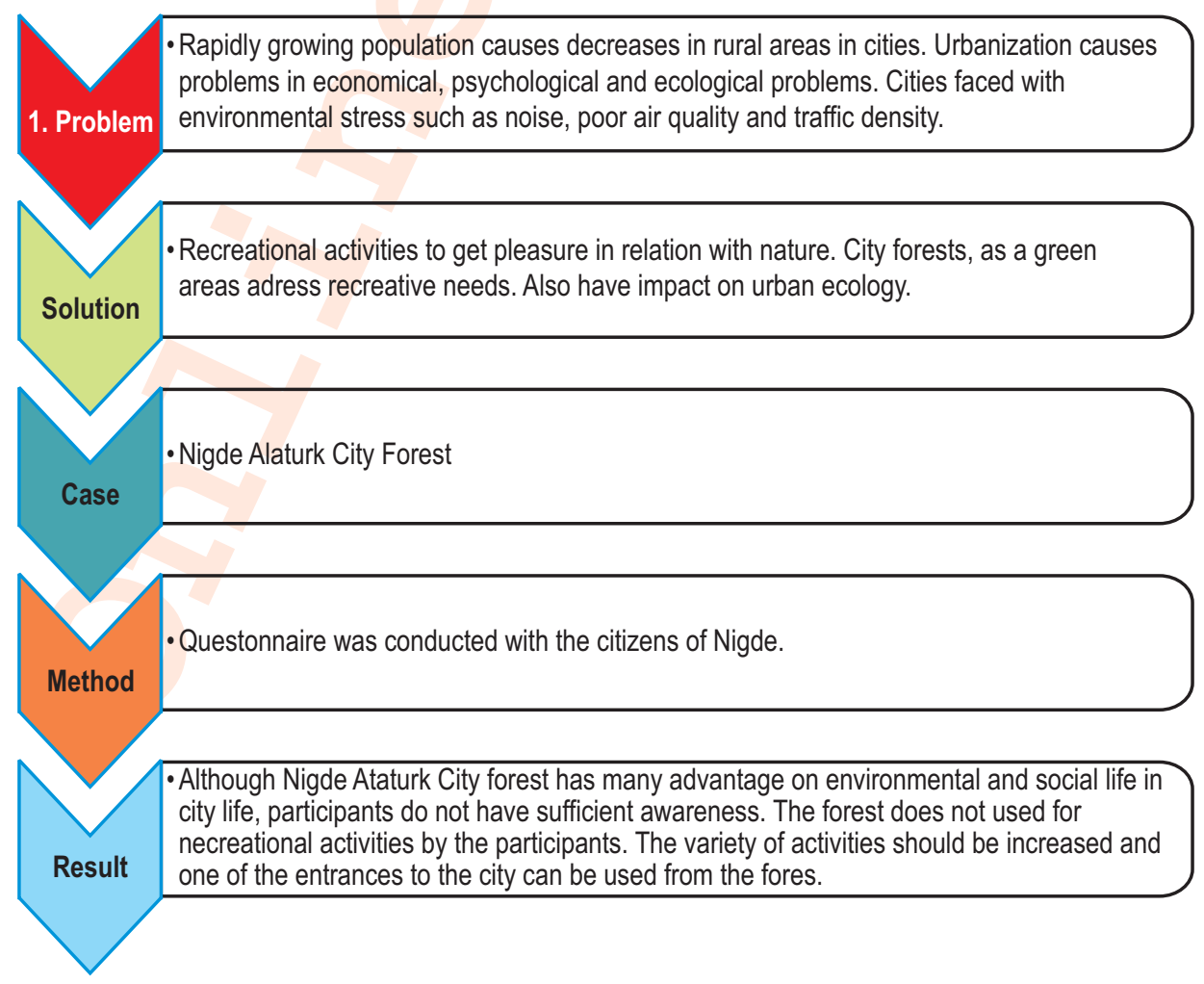

How to cite : Karafakı, F.C. and Ç. Çetin: Ecological impacts of a city forest and level of public awareness for recreational use of Nigde Atatürk city forest. J. Environ. Biol., 41, 318-322 (2020). 


\section{Introduction}

The rising growing population and opportunities of employment and facilities of modern life style of cities urges people to migrate to cities. Therefore, rural areas are rapidly changing into urban areas. Those cities where urbanization process has not managed in a controlled manner, has led to serious economic, psychological and ecological problems over time. People need areas which can be physically used by them, while struggling with the burdens of city life. They can relax mentally in such places and can improve their quality of life. The ecological benefits provided by such areas to the city are great. In some cities, these needs can be met due to abundance of natural environment, while in others it is possible to meet them by means of artificially constructed natural environment.

Today cities are facing great environmental stress such as noise, poor air quality and traffic density. Increasing green areas in a sustainable way has a huge potential to mitigate the negative impacts of urbanization, make cities more attractive to live in, stop unplanned urbanization and decrease demand for transportation (De Ridder et al., 2004).

Recreational activities performed in order to get pleasure in relation with nature are becoming more and more popular in cities. Urban parks serve the same environmental and recreational functions as forests and green spaces, albeit in a smaller scale (Morancho, 2003). However, it is difficult to find the diversity of life that forests encompass and the cultural and economic assets they deliver to the cities. The parks to some extent, but help if they are not planned in line with a system and remain merely as green urban patches they will not have much impact. Within this context, city forests are large-scale patches of green that address creative needs of city dwellers.

From a general perspective, forest is an ecosystem symbolizing the mutual web of relations that is jointly formed by trees and other plants, animals, microorganisms and environmental factors such as soil, air, water, light and heat. Forest is a mutuality of life in which the forest trees higher than $5 \mathrm{~m}$ are dominant and are close to affect each other, and constitute unique conditions of climate and habitat (Ozturk et al., 2010). Forest as such is defined as a partnership of life, a mutuality of life, an ecosystem and even as a huge living organism comprising numerous plants and animals (Akyuz et al., 2014).

City forests, on the other hand, are areas found naturally within and nearby cities or established artificially, which provide urban structure with aesthetic and functional contributions, and also offer recreative facilities as well as more comfortable environmental conditions to city dwellers, contributing to physiological, psychological, economic and social development of urban dwellers while affecting urban ecology considerably. City forests are accessible at short distances and this increases their usage rates. According to Konijnendik (2003) and Tilki et al. (2008), city forests "are forested areas planned within or around the city in order to meet the recreational needs of city dwellers".City residents with time have gradually understood the importance of city forests better as the main component of cityscape, urban infrastructure and quality of life. Municipalities have initiated highly assertive forestry programs together with various shareholders. Though this process has been well achieved in industrialized countries, it is still in its infancy in the industrialising countries (Kuchelmeister, 2000).

Turkey is facing a rapid urban sprawl particularly over the last 30 years, deprived of necessary infrastructure. From 1965 to 1975, Turkey was first among western countries in terms of population growth rate and urbanization. In this period, while the population of the country rose by $25 \%$, the rate of urbanization was twice this figure, i.e., $51 \%$. People continuously emigrated from rural areas towards the cities, therefore all big cities grew by $8 \%$ each year. Due to large-scale environmental and health problems at present, it is becoming an obligation to create considerable ecological and aesthetic settings and enhance urban life quality (GulandSezer, 2009).

City forests increase urban life quality by bringing various ecological, cultural and economic benefits to the city. They create a microclimatic environment, with positive effects on the urban climate. Their functions are paramount in terms of enhancing air quality, feeding water resources, preventing soil erosion and protecting biological diversity. Apart from these benefits, they are places where a relation between nature and humans can be built for the urban dweller longing for the nature in the urban environment. Furthermore, they are meeting spots for people from different status. The reason why ancient communities established their settlements near forested areas was the need for food, accommodation, and firewood as well as the sense of protection, security and peace they give against enemies. With all these benefits, it is seen that in addition to profound importance of city forests as part of urban open-green space system, they are also important for psychological and sociological development of urban dwellers.

The main purpose behind establishing of city forests is to formulate plans towards enhancing the life quality of urban dwellers, such as meeting the recreative needs of urban people and enabling people who live under intense pressure of the city to be in touch with nature along with facilitating positive impacts on urban ecology. In this respect, it is important that during the process of establishing city forests and managing their use in a sustainable way, the culture of urban dwellers and their expectations from their use of forest are figured out and incorporated into the process. This approach will increase the public satisfaction and enable their integration with the city. 
This study aimed to reveal the effects of city forests on urban ecology, scrutinize the contributions of Nigde Ataturk City Forest, established in the city of Nigde in 2007 and finally find the awareness level of inhabitants of Nigde about the city forest.

\section{Materials and Methods}

Nigde Ataturk City Forest was selected as the research area. It is located $6 \mathrm{~km}$ from the city center (Table 1). Nigde Ataturk City Forest covers an area of 50 ha. It has cedar (Cedrus sp.), black pine (Pinus nigra), almond (Prunus sp.) trees together with multiple broad-leaved species of various heights. The area is rich in wildlife. Approximately, 75 tons of carbon is stored by Nigde Ataturk City Forest, which corresponds to 275 tons of $\mathrm{CO}_{2}$ in the atmosphere (City Forests Book, 2009). There are facilities like playgrounds, watchtowers, pergolas, sitting benches, covered and uncovered picnic tables, ornamental ponds, fountains, walking grounds, walking tracks, a restaurant, information building and WC.

In this study, a survey was conducted using random sampling method in order to assess the level of public consciousness. The semi structures questionnaires were prepared for the field study. Keeping in view the aim of this study in view, we tried to determine the impact of city forest on the users in Nigde city center. The population of Nigde city center was taken as the sample on which the survey was performed. According to 2014 population census, 149.696 people in Nigde province live in the city center. The number of female and male inhabitants living in the city is quite close to each other (Anonymous, 2015).

The formula given below was used in the survey study

$n=\frac{\text { Z.Z. N.P.Q. }}{\text { N.D. D. + Z.Z.P. Q }}$

$1.96 \times 1.96 \times 149.696 \times 0.95 \times 0.05$

$\mathrm{n}=\frac{1.96 \times 1.96 \times 149.696 \times 0.95 \times 0.05}{149.696 \times 0.05 \times 0.05+1.96 \times 1.96 \times 0.950 .05}$

$n=\frac{27315.927296}{374.422476}$

$n=72.9548=73$

$\mathrm{n}$ : Sample size, Z: the value of $Z$ according to $95 \%$ confidence interval (1.96), N: Ground mass size, $\mathrm{P}$ : the probability of the existence of the feature intended to be measured within the ground mass (95\%), D: error acceptance rate (5\%), Q: 1-P (Kalıpsız 1981, Karasar 1991,Ozdamar 2003, Akten, 2003, Sandal and Karademir, 2013).

Following the calculation, it becomes apparent that the survey must be applied to 73 people. In order to increase the reliability of the study, the questionnaire was conducted on 100 people.

\section{Results and Discussion}

This study aims to reveal the ecological impacts of city forests and the level of public awareness on the recreational use of Nigde Ataturk City Forest. 50\% of the participants who took part in the survey were aged $26-45$ years, $50 \%$ were females, $60 \%$ were married, $48 \%$ were university graduates, $57 \%$ were employed and $38 \%$ had salaries between $\$ 178$ and $\$ 536$. This result indicates that most of the participants have the ability to use a recreative area in terms of characteristics like age, economic level, and level of consciousness. Nevertheless, using a recreative area is principally possible through recognition of that area. The study showed that Nigde Ataturk City Forest is not an area the city inhabitants use intensely for their recreative needs. The survey revealed that in Nigde city center $80 \%$ of the participants did not consider Nigde as a green city. They think that green spaces in the city center are inadequate. Out of $89 \%$, only $25 \%$ are aware of the city forest as a part of urban open-green space system. Nearly, $68 \%$ stated that they do not take advantage of Nigde Ataturk City Forest. This might be because public awareness has not developed much on the issues like using the city forest and building a relationship. This is because of the inadequacy of forested areas due to the physical conditions of the city. Moreover, the concerns of privacy, which the people brought from their past and harsh conditions of summer and winter have pushed people towards adopting a self-enclosed lifestyle. This situation keeps the public, who are not familiar with the concept of city forest, from using the city forest, established at a later date. The city forest currently consist of young trees and the density of trees is low, which does not create a feeling that there is a forest when observed from outside. Furthermore, the area is mostly used by men or university students studying at Nigde, which restricts families from using this area. It was also observed that the use of Nigde Ataturk City Forest becomes intense during holidays (weekend holidays, national holidays, etc.). More families use the area during these days. The reason for this might be to allow the visitors think that family use of the area is lower on other days and monotype users will be higher (men only, young people only, etc.). Among the answers given to the question "what restricts your use of city forest", the biggest percentage mentioned security weakness $(21 \%)$, pollution $(20 \%)$ and existence of monotype users (19\%). There are security guards in the area, but the city forest is reached by transportation. This adds to its isolation and a monotype user domination. The sense of security disappears, therefore, limited use of area is regarded natural.

The answers the participants gave to the question "what is your reason to go to the city forest" was mainly as picnic spot $(23 \%)$, city forest offers an opportunity to have relaxation (18\%) and there is no other place to go in Nigde city center (17\%). One possible reason for this is that there is not a wide variety of activities within the forest area that will attract the attention of 
Table 1 : List of Green Areas in the City Center of Nigde (Niðde Municipality Directorate of Parks and Gardens. 2015)

\begin{tabular}{|c|c|c|c|}
\hline Name of the park & Total area $\left(\mathrm{m}^{2}\right)$ & Name of the park & Total area $\left(\mathrm{m}^{2}\right)$ \\
\hline Faculty of Education Park & 1461,61 & Saglik Park & 2402,56 \\
\hline Fatih Park & 578,79 & OzlemSirinNatura Park & 3009,59 \\
\hline Kayali Park & 2981,74 & Sultan Park & 3920,83 \\
\hline Kemal Aydogan Park & 1512,08 & Yildirim Park & 361,97 \\
\hline MuhsinYazicioglu Park & 4160,27 & Caglayan Park & 2470,00 \\
\hline NasrettinHoca Park & 1056,70 & Uydukent Park & 719,98 \\
\hline Ozbelde 1. Park & 993,67 & Vali Yazicioglu Park & 2262,94 \\
\hline Ozbelde 2. Park & 1156,09 & Kale Parki & 16964,82 \\
\hline Ozbelde 3. Park & 5985,56 & KucukEv Park & 1441,59 \\
\hline Ozbelde 4. Park & 2399,66 & Pasa Mosque Park & 616,79 \\
\hline Ozbelde 5. Park & 2398,17 & Esenbey Garden & 429,57 \\
\hline Suman Park & 779,47 & Kesikbas Garden & 690,67 \\
\hline Serif Ali Mosque Park & 1978,50 & Old Zahire Bazaar Park & 2470,40 \\
\hline Topcu Park & 791,45 & Meliksah Park & 1696,83 \\
\hline Ozbelde 6. Park & 29220,98 & Kilicarslan Park & 3074,48 \\
\hline Pinar Park & 655,20 & Abilayhan Park & 4017,78 \\
\hline Vali Park & 785,00 & 19 Mayis Park & 2525,60 \\
\hline Hospital Park & 3531,72 & Aşiyan Park & 1093,02 \\
\hline HaciBektas Park & 3045,87 & Selcuk Park & 2290,39 \\
\hline Mevlana Park & 7111,17 & Nig-Kur Park & 1289,68 \\
\hline Piri Reis Park & 1086,51 & Karanfil Park & 1334,68 \\
\hline Selaleli Park & 640,07 & SarayArkası Park & 1559,98 \\
\hline YunusEmre Park & 2259,65 & Binevler Park & 2772,11 \\
\hline Swimming Pool & 1910,32 & Ahmet Yesevi Park & 601,66 \\
\hline CifteMinarei Mosque Park & 6923,65 & AleaddinKeykubat Park & 1459,36 \\
\hline Murat Cami Park & 3065,97 & EskiMezbaha Park & 1752,06 \\
\hline MuzafferEcemis Park & 10583,13 & Ata Sanayi Park & 5643,59 \\
\hline Sayginevler Park & 2701,63 & İlhanli5.Sokak Park 1 & 319,21 \\
\hline UcgenVallet Park & 1148,92 & İlhanli5.Sokak Park 2 & 2125,59 \\
\hline SabihaSahenk Sport Center Garden & 4322,58 & İlhanli5.Sokak Park 3 & 3493,18 \\
\hline 23 Nisan Park & 1619,05 & Ddy Gar Build Park & 16414,95 \\
\hline 66 EvlerFuzuli Park & 1065,19 & Dedelibag Park25 & 17,09 \\
\hline Bazaar Park & 6128,94 & Insel Mosque Park & 3441,81 \\
\hline Dortayak Mosque Park & 610,35 & FotoUnal Park & 981,97 \\
\hline HudaventHatun Park & 7672,28 & Memnune Park & 6227,04 \\
\hline Kilimci Park & 534,60 & Sehitler Mosque Park & 1939,20 \\
\hline SuleymanSah Park & 524,95 & Rahman Mosque Park & 4981,12 \\
\hline Aga Yusuf Park & 1618,85 & MaresalFevziCakmak Park & 13372,26 \\
\hline 30 Agustos Park & 5589,71 & Nar Mosque Park & 1576,43 \\
\hline YesilkentGuney Park & 2852,50 & Nar Garden & 650,19 \\
\hline YesilkentGuney Park & 3545,37 & Tepebaglari Green Area & 9445,30 \\
\hline Melle Park & 39841,04 & City Forest & 2970,00 \\
\hline
\end{tabular}

public. The fact that there are no different recreation areas in the Nigde city center to be utilized as open-green space is another reason for the preference of the area during holidays. The participants mostly answered the question "which activities would you like to be brought to the city forest" as plant compositions (21\%), open sport areas (20\%) and cafes and restaurants to be used in all seasons (19\%). The participants chose these answers because the forest does not give the sense of a true forest, it is young, it does not appeal to the young since there are no open sport areas integrated into the area and finally enclosed spaces established within the forest are few and should be increased in a way that will be suitable for family budgets of inhabitants of Nigde in harsh winters.

Most of the participants are of the opinion that city forests are natural green areas located within or around the city area which can offer recreative areas to people (46\%). Furthermore, $52 \%$ of the participants stated that city forests are areas where the 
inhabitants of the city can relax and go for a walk at weekends. Majority (58\%) of participants think that these places are used as picnic spots, which indicates that awareness on diversity of city forest uses among the public has not yet developed adequately. The participants also state that city forests are developed to afforest the city $(49 \%)$ and they do not exist naturally within the city $(47 \%)$, but are established later, probably not a welldeveloped forest area or an organized recreation area in the same location prior to the addition of Nigde Ataturk City Forest to the city in 2007. A great majority of participants do not agree with the notion that city forests are areas established in order to stop the expansion of city $(54 \%)$ and they do not think city forests are established so that they can be used in the industry sector of the city $(69 \%)$ or are plantation areas created for the firewood (85\%). This situation results from the fact that the forest area is still quite young, and no forest products can be obtained from the area yet. This result also shows that the level of consciousness is rather low among the public about the industrial benefits of forests.

Most of the participants think that city forests provide city with clean air (75\%), control winds over the city (46\%) and bring visual richness $(60 \%)$ to the city, which shows that the public is aware of some ecological and aesthetic benefits city forests bring to the city. Again, the participants think forests are places in which urban dwellers can build mutual communication (46\%). This is an indication that the awareness of forests being a social setting is gaining ground. However, most of the participants are not of the opinion that the areas of city forests are habitats for wildlife and native plants (38\%) and they prevent noise (41\%).

It was concluded that the participants of the survey had inadequate levels of consciousness on the benefits of city forest to the ecology and social life of the city. They also had insufficient knowledge on various uses of forest. The presence of urban forest in a city adds many economic, ecological, aesthetic and social values to the city. A healthy city forest that can be used properly in a recreative way and that has spread to a large area gives the city a green character, regulates the urban climate, increases the quality of air and weather, protects soil and enriches biological diversity. When considered from this point of view, it is crucial that Nigde Ataturk City Forest needs to be improved considering the characteristics of city forests listed above, and the public be made more aware of the use of such areas in terms of bringing the public and nature together. Additional activities brought to such a forest area will increase the intensity of use of this area. Apart from its recreational use, area can also be improved so that it can be used towards education. Moreover, celebrations, charity sales and exhibitions can be organized on special occasions in designated places within its borders. The fact that Nigde Ataturk City Forest is located on one of the main entrance points of the city, increases the value of the area. Creating a developed perception of forest will serve as a significant factor that will give city a distinctive character at the entrance to the city.

\section{Acknowledgments}

We would like to thank Nigde Municipality Parks and Gardens Department, Nigde Provincial Special Administration, Nigde Governorship Provincial Directorate of Environment and Urbanization for their permission and support of using data.

\section{References}

Akten, M.: Determination of the existing potentials of some recreational areas in Isparta province. SDU Facul. For. J., A(2), 115-132 (2003).

Akyuz, H., M. Kul and F. Yasartürk: Forests and environmentin terms of recreation. Inter. J. Sci. Cult. Sport, 1, 881-890 (2014).

Anonymous: www.nigde.gov.tr/ population-and-distribution. html\#.vqnantksvlw. Accessed 11 February 2015.

City Forests Book: T.C. Ministry of Forestry and Water Affairs General Directorate of Forestry. Esta Ltd., Ankara, Turkey (2009).

De Ridder, K., V. Ademec, A. Bañuelos, M. Bruse, M. Bürger, 0. Damsgaard, J. Dufek, J. Hirsch, F. Lefebre, J.M. Pérez-Lacorzana, A. Thierry and $C$. Weber: An integrated methodology to assess the benefits of urban green space. Sci. Total Environ., 334, 489-497 (2004).

Gul, A. and A. Gezer: Conceptual urban forestry, technical and cultural approaches. SDU Facul. Forestry J., 86, 142(2009).

Kalıpsız, A.: Statistical Methods. IU.Faculty of Forestry Publication, Istanbul, Turkey (1981).

Karasar, N.: Scientific Research Method, Concepts, Principles. Techniques. Sanem Printing, Ankara, Turkey (1991).

Kiper, T. and A.G. Oztürk: Urban forest recreation and local people's awareness about example of Edirne urban (İzzetArseven) forest. J. Tekird. Agric. Facul., 8, 105-117(2011).

Konijnendik, C.A.: Decade of urban forestry in Europe. Forest Policy Econ., 5, 173-186(2003).

Kuchelmeister, G.: Trees for the urban millennium: urban forestry update. Unasylva, 200, 49-55 (2000).

Morancho, A.: Hedonic valuation of urban green areas. Landscape Urban Plan., 66, 35-41(2003).

Ozdamar, K.: Modern Scientific Research Methods. Kaan Bookstore, Eskişehir, Turkey, pp. 158-160 (2003).

Ozturk M., S. Gucel, K. Ozkan, M. Kucuk and A.K. Saxena: ForestsForestry Environment in Turkey. J. Environ. Biol. (Special Issue), $31,245(2010)$.

Sandal, E.K. and N. Karademir: Determination of people's expectations and consciousness with adequacy of green spaces in Kahramanmaraş. East. Geograph. Rev., 29, 155-176 (2013).

Tilki, F., S. Guner and A. Tufekçioğlu: Urban forestry and its practices in Artvin. ACU J. For. Fac., 9, 92-100 (2008). 